\title{
Het gebrekkige afspiegelen door het UWV
}

\author{
mr. Rachel Rietveld*
}

\section{Inleiding}

Naast het wettelijke ontslagrecht zijn met de invoering van de Wwz ook de regels omtrent de afspiegeling en de ontslagvolgorde (meerdere malen) gewijzigd. De groepen werknemers waarvan de werkgever als eerste afscheid moet nemen bij een reorganisatie zijn iets aangepast. Deze groepen werknemers worden niet buiten de afspiegeling gelaten, maar meegenomen in de verdeling die wordt gemaakt over vijf leeftijdsgroepen. Ongeacht deze verdeling, worden vervolgens de tot deze groepen behorende werknemers wel alsnog het eerst voor ontslag voorgedragen. Hoewel het eerst meenemen van deze groepen werknemers in de afspiegeling om ze vervolgens als eerste voor ontslag in aanmerking te laten komen omslachtig lijkt, kan deze nieuwe werkwijze goed worden gerechtvaardigd. Het doel van afspiegelen is dat de samenstelling van het personeel, verdeeld over vijf leeftijdsgroepen, na de ontslagronde zo veel mogelijk gelijk is aan de onderlinge verhoudingen van vóór de gedwongen ontslagen. In dit artikel ga ik in op de regels die het UWV heeft gesteld voor het opstellen van de ontslagvolgorde en de afspiegeling. Ik meen dat het UWV de Uitvoeringsregels ontslag wegens bedrijfseconomische redenen (Uitvoeringsregels) ${ }^{1}$ niet helemaal juist toepast. Daarnaast blijken de Uitvoeringsregels zelfs incompleet te zijn, zodat in bepaalde situaties andere werknemers voor ontslag in aanmerking dienen te worden gebracht dan volgens het UWV zou moeten. De onjuiste toepassing van de door het UWV zelf opgestelde regels is mij opgevallen in verband met de ontwikkeling van een afspiegelingstool, met als doel in enkele stappen de hele afspiegeling te kunnen bepalen. Daarvoor moet, conform het doel van afspiegeling, gekeken worden naar proportionaliteit tussen het aantal werknemers binnen een leeftijdsgroep voor en na de ontslagronde. In de inmiddels ontwikkelde tool wordt rekening gehouden met werknemers in groepen 2 tot en met 4 (zie volgende paragraaf), maar ook met bijvoorbeeld de onmisbare werknemer. Het UWV biedt een hulpmiddel aan degene die de juiste ontslagvolgorde moet vaststellen in de vorm van een Excelbestand. Dit
Excelbestand wordt in de volgende paragrafen aangehaald, waarbij wordt laten zien dat de uitkomst in sommige gevallen anders zou moeten zijn.

\section{Eerst beëindigen andere arbeidsrelaties}

Artikel 7:671a lid 5 BW en de Ontslagregeling ${ }^{2}$ bepalen welke werknemers buiten de afspiegeling moeten worden gehouden. De Uitvoeringsregels specificeren wie wel en niet meegaan in de afspiegeling en dat leidt ertoe dat de werknemers in groepen moeten worden ingedeeld. Het gaat om de werknemers werkzaam op arbeidsplaatsen die vervallen, samen met eventueel werknemers op uitwisselbare functies binnen de bedrijfsvestiging(en). ${ }^{3}$ De werknemers in de groepen 2 tot en met 4 (zie hierna) worden - zoals aangestipt - het eerst ontslagen, maar worden wel meegenomen in het personeelsoverzicht voor de afspiegeling. Pas na de afvloeiing van de werknemers in de groepen 2 tot en met 4 , komen werknemers in groep 5 in aanmerking voor afvloeiing. ${ }^{4}$ De groepen 1 tot en met 5 zijn als volgt ingedeeld:

1. gedetacheerden en uitzendkrachten, zzp'ers en ingeleende werknemers van een andere bedrijfsvestiging;

2. (payroll)werknemers die AOW-gerechtigd zijn;

3. (payroll)oproepkrachten met een nulurencontract. ${ }^{5}$

4. (payroll)werknemers met een arbeidsovereenkomst voor bepaalde tijd die binnen 26 weken na het moment van beslissing op de aanvraag afloopt.

5. (payroll)werknemers met een arbeidsovereenkomst voor onbepaalde tijd of met een overeenkomst voor bepaalde tijd die langer dan 26 weken doorloopt, gerekend vanaf het moment van beslissing op de aanvraag.

Alle in groep 2 tot en met 5 genoemde werknemers worden meegenomen in de afspiegeling. Alleen groep 1 blijft volledig buiten beeld. De contracten van de onder groep 1 vallende personen worden eerst beëindigd wan-

Rachel Rietveld is onderzoeker bij ArbeidsmarktResearch UvA B.V. (www.magontslag.nl). Zij ontwikkelt digitale beslisbomen waarmee de gebruiker een inschatting krijgt van zijn rechtspositie bij eventueel ontslag en andere (reken)tools.

1. Uitvoeringsregels ontslag wegens bedrijfseconomische redenen, versie juli 2016 (Uitvoeringsregels). 
Tabel 1

\begin{tabular}{|c|c|c|c|c|c|c|}
\hline Leeftijdsgroep & 1 (15-25 jaar) & 2 (25-35 jaar) & 3 (35-45 jaar) & 4 (45-55 jaar) & $5(55$ jaar +$)$ & TOTAAL \\
\hline Aantal werknemers & 10 & 18 & 25 & 9 & 5 & 67 \\
\hline Verdeling & 2,239 & 4,030 & 5,597 & 2,015 & 1,119 & 15 \\
\hline $\mathrm{Na}$ gehele getallen & 2 & 4 & 5 & 2 & 1 & 14 \\
\hline O.b.v. decimalen & - & - & 1 & - & - & 1 \\
\hline Totaal & 2 & 4 & 6 & 2 & 1 & 15 \\
\hline
\end{tabular}

Verdeling van werknemers in uitwisselbare functies over leeftijdsgroepen.

Tabel 2

\begin{tabular}{lllllll}
\hline Leeftijdsgroep & $\mathbf{1}$ (15-25 jaar) & $\mathbf{2}$ (25-35 jaar) & $\mathbf{3}$ (35-45 jaar) & $\mathbf{4}(\mathbf{4 5 - 5 5}$ jaar) & 5 (55 jaar + ) & TOTAAL \\
\hline Aantal groep 2 t/m 4 & 3 & 0 & 1 & 3 & 2 & 9 \\
\hline Oorspronkelijk aantal & 2 & 4 & 6 & 2 & 1 & 15 \\
\hline Aantal te leveren & 3 & 4 & 6 & 3 & 2 & 18
\end{tabular}

Werknemers in groep 2 tot en met 4 zorgen voor problemen in het vast te stellen aantal per leeftijdsgroep.

neer arbeidsplaatsen vervallen. ${ }^{6}$ Wie daarna voor ontslag in aanmerking komt, wordt bepaald door het afspiegelingsbeginsel. In dat kader worden degenen in groep 2 tot en met 5 ingedeeld in vijf leeftijdsgroepen, te weten 15 tot 25 jaar, 25 tot 35 jaar, 35 tot 45 jaar, 45 tot 55 jaar en 55 jaar en ouder. De arbeidsrelaties van arbeidskrachten in groep 2 tot en met 4 worden dus in eerste instantie niet eerst beëindigd.

\section{Afspiegelen volgens het UWV}

3.1 De leemte in de rekenvoorbeelden

Zoals gezegd maakt het UWV bij de toepassing van het afspiegelingsbeginsel een verdeling over de vijf verschillende leeftijdsgroepen. De verdeling wordt gemaakt door het aantal werknemers in de leeftijdsgroep te delen door het totaal aantal werknemers binnen de uitwisselbare functie(s). De uitkomst moet worden vermenigvuldigd met het aantal benodigde ontslagen, dat resteert na afvloeiing van de onder groep 1 ressorterende werkenden. Het gaat om werknemers en niet om het aantal fte dat de werkgever wil verminderen. De gehele getallen geven de eerste aantallen ontslagen per leeftijdsgroep. In de meeste situaties zal de som van de hele getallen onvoldoende zijn om het gewenste aantal ontslagen te

6. Alleen van echte zelfstandigen die werkzaamheden verrichten die voor een doelmatige bedrijfsvoering door zelfstandigen moeten worden verricht, hoeft geen afscheid te worden genomen. Ook als uitbesteding van werkzaamheden de bedrijfseconomische reden voor de ontslagen is, kunnen de zelfstandigen blijven als zij werkzaam zijn op arbeidsplaatsen met diezelfde werkzaamheden. bereiken, dus moet de leeftijdsgroep die het hoogste getal achter de komma heeft - de hoogste fractie - een extra werknemer leveren. Dit gebeurt net zo lang tot het gewenste aantal is bereikt.

In het voorbeeld te zien in tabel 1 moeten 15 werknemers ontslagen worden. Op basis van de gehele getallen komt men op 14 ontslagen, zodat uit leeftijdsgroep 3 een extra werknemer wordt ontslagen. Deze werknemer wordt geselecteerd op basis van de fractie die in dit geval in die groep het hoogst is, in casu 0,597.

Wanneer nu sprake is van werknemers uit groepen 2 tot en met 4, dus werknemers met bijvoorbeeld een aflopend dienstverband of die AOW-gerechtigd zijn, ontstaan problemen met de afspiegeling. Door de aanwezigheid van werknemers in de groepen 2 tot en met 4 in de verschillende leeftijdsgroepen, moeten sommige leeftijdsgroepen mogelijk meer werknemers voor ontslag leveren dan volgens de berekening die in eerste instantie (hierboven) is gemaakt. Dit zijn immers de bijzondere werknemers die als eerst voor ontslag in aanmerking dienen te komen en de verdeling over leeftijdsgroepen staat daaraan niet in de weg. Als werknemers uit de groepen 2 tot en met 4 eerst afvloeien en de leeftijdsgroepen het originele aantal blijven leveren, wordt het totaal aantal ontslagen hoger dan het aantal noodzakelijke ontslagen. Zie tabel 2 als voorbeeld, waarbij het nog steeds gaat om 15 gewenste ontslagen, maar waarbij nu werknemers uit de groepen 2 tot en met 4 zijn aangegeven.

Om dit probleem op te lossen geeft het UWV aan dat de leeftijdsgroepen die op basis van de hoogste fractie en dus in laatste instantie een (extra) werknemer hebben geleverd, dit ter compensatie van het te hoog geworden 
aantal ontslagen niet meer hoeven te doen. Aangezien in bovenstaand voorbeeld alleen leeftijdsgroep 3 een extra werknemer leverde, maar er drie werknemers te veel op de voordrachtlijst staan, biedt de toelichting van het UWV hiervoor geen oplossing. Er is op basis van de door het UWV gegeven uitleg geen antwoord te geven op de vraag welke groepen minder werknemers hoeven te leveren teneinde op de noodzakelijke 15 uit te komen. Alhoewel dit niet uit de Uitvoeringsregels blijkt, gebruikt het UWV voor dit probleem een andere manier van afspiegelen: een rangordelijst. Dit valt af te leiden uit het Excelbestand dat vanaf de website kan worden gedownload $^{7}$ en uit het antwoord van het UWV op vragen over het afspiegelingsprobleem.

\subsection{Het lastige van de rangordelijst}

Het UWV maakt dus een rangordelijst om zo te bepalen welke werknemers voor ontslag in aanmerking komen. Dit is een andere manier dan het vaststellen van de volgorde voor ontslag zoals hiervoor beschreven, wat ik voor het onderscheid de 'tabelmethode' noem. De rangordelijst leidt tot andere uitkomsten wat betreft werknemers die voor ontslag in aanmerking komen, wat in paragraaf 3.3 geillustreerd wordt en wat een van de problemen van deze werkwijze is.

De rangordelijst wordt gemaakt door het aantal werknemers in de verschillende leeftijdsgroepen te delen door het totaal aantal werknemers binnen de uitwisselbare functie(s). In tegenstelling tot bij de tabelmethode wordt de fractie vervolgens niet vermenigvuldigd met het aantal gewenste ontslagen. De resulterende getallen geven de (oorspronkelijke) verdeling van werknemers over de leeftijdsgroepen aan. De hoogste breuk geeft aan welke leeftijdsgroep de eerste werknemer moet leveren. Dit is degene met het kortste dienstverband binnen die leeftijdsgroep. Deze stap wordt herhaald tot alle werknemers een plek in de rangorde hebben gekregen. Bij elke stap wordt het getal voor een leeftijdsgroep bepaald door het getal uit stap 1 te vermenigvuldigen met het 'stapnummer'(zie de eerste kolom in de volgende tabel). Bij iedere stap wordt van het zo berekende getal per leeftijdsgroep het aantal werknemers afgetrokken dat deze leeftijdsgroep al in voorgaande stappen voor ontslag heeft geleverd, omdat anders steeds dezelfde leeftijdsgroep het hoogste getal zou hebben en dus alle ontslagen zou moeten leveren. Ook in deze methode worden de bijzondere werknemers uit de groepen 2 tot en met 4 meegenomen in de verdeling. In hetzelfde voorbeeld als hiervoor (15 van de 67 werknemers moet afvloeien en van de 67 werknemers behoren 9 werknemers tot de groepen 2 tot en met 4) zou de tabel er als volgt uit komen te zien, waarbij de dikgedrukte getallen aangeven welke leeftijdsgroep een werknemer voor ontslag levert in die stap en tussen haakjes de som staat die tot de fractie leidt.
Dezelfde verdeling over de leeftijdsgroepen is ontstaan als in de tabel 1 onder paragraaf 3.1, zodat nu ook hier de volgende stap moet worden genomen; het eerst laten afvloeien van de werknemers uit groep 2 tot en met 4 . Zij worden immers met voorrang ontslagen. Dit is niet mogelijk, tenzij meer dan vijftien stappen worden gezet. Dat komt doordat (in dit geval) nog niet alle werknemers uit groep 2 tot en met 4 voor ontslag zijn voorgedragen na vijftien stappen (15 voorgedragen ontslagen). Door extra stappen te zetten tot het aantal bijzondere werknemers in iedere leeftijdsgroep is 'afgedekt', wordt dit probleem opgelost. Pas dan kan worden bepaald welke leeftijdsgroepen een werknemer minder hoeven te leveren, ter correctie of compensatie van het te hoge aantal werknemers dat nu voor ontslag in aanmerking zou komen. De keuze wordt nog steeds bepaald door de hoogste fractie. In tabel 4 is aangegeven waar in de rangorde de werknemers uit de groepen 2 tot en met 4 staan en waarom dus tot en met stap 20 moet worden doorgegaan om deze werknemers allemaal te vinden.

Twintig werknemers komen volgens de rangorde voor ontslag in aanmerking. Pas bij stap 20 wordt namelijk de tweede, verplicht voor ontslag in aanmerking komende werknemer in leeftijdsgroep 5 gevonden, omdat in die leeftijdsgroep twee werknemers uit de groepen 2 tot en met 4 zitten. Dit zijn vijf stappen te veel ten opzichte van het gewenste aantal ontslagen en dus moet vanaf stap 20 worden teruggelopen. Daarbij moet nog steeds rekening worden gehouden met de leeftijdsgroepen die zeker een werknemer moeten leveren omdat die werknemer in groep 2 tot en met 4 valt. De keuze wordt voor de eerste twaalf ontslagen nog steeds bepaald door de hoogste fractie, maar in dit voorbeeld vanaf de dertiende stap dus niet meer. Vanaf daar wordt gekeken of de hoogste fractie valt in een leeftijdsgroep die door het nog niet bereikte aantal bijzondere werknemers nog niet genoeg werknemers heeft geleverd. In de vorige tabel was al te zien dat in de laatste stappen nog drie werknemers uit de groepen 2 tot en met 4 werden gevonden. Zo is te zien dat bij de zestiende stap pas weer een werknemer voor ontslag in aanmerking komt, omdat de hoogste fractie daar in leeftijdsgroep 1 valt en die leeftijdsgroep dan de derde noodzakelijke werknemer kan leveren. Het is dus een kwestie van zoeken naar alle bijzondere gevallen en die steeds inruilen voor werknemers in leeftijdsgroepen die al wel genoeg hebben geleverd om aan de aantallen in de bijzondere groepen te komen. In de volgende tabel geven de cursieve cellen de bijzondere werknemers (groepen 2 tot en met 4) aan die voor ontslag in aanmerking moeten worden gebracht en de dikgedrukte getallen welke overige (groep 5) volgens de rangordelijst voor ontslag in aanmerking komen.

$\mathrm{Nu}$ is de rangorde bepaald en moet voor de dikgedrukte aantallen alleen nog gekeken worden welke werknemers 
Tabel 3

\begin{tabular}{|c|c|c|c|c|c|c|}
\hline Leeftijdsgroep & 1 (15-25 jaar) & 2 (25-35 jaar) & 3 (35-45 jaar) & 4 (45-55 jaar) & $5(55$ jaar +$)$ & TOTAAL \\
\hline Aantal werknemers & 10 & 18 & 25 & 9 & 5 & 67 \\
\hline \multicolumn{7}{|l|}{ Stap } \\
\hline 1 & 0,15 & 0,27 & 0,37 & 0,13 & 0,07 & 1,00 \\
\hline 2 & 0,30 & 0,54 & $(0,75-1=)-0,25$ & 0,27 & 0,15 & 1,00 \\
\hline 3 & 0,45 & $(0,81-1=)-0,19$ & $(1,12-1=) 0,12$ & 0,40 & 0,22 & 1,00 \\
\hline 4 & $(0,60-1=)-0,40$ & $(1,07-1=) 0,07$ & $(1,49-1=) 0,49$ & 0,54 & 0,30 & 1,00 \\
\hline 5 & $(0,75-1=)-0,25$ & $(1,34-1=) 0,34$ & $(1,87-1=) 0,87$ & $(0,67-1=)-0,33$ & 0,37 & 1,00 \\
\hline 6 & $(0,9-1=)-0,10$ & $(1,61-1=) 0,61$ & $(2,24-2=) 0,24$ & $(0,81-1=)-0,19$ & 0,45 & 1,00 \\
\hline 7 & $(1,04-1=) 0,04$ & $(1,88-2=)-0,12$ & $(2,61-2=) 0,61$ & $(0,94-1=)-0,06$ & 0,52 & 1,00 \\
\hline 8 & $(1,19-1=) 0,19$ & $(2,15-2=) 0,15$ & $(2,99-3=)-0,01$ & $(1,07-1=) 0,07$ & 0,60 & 1,00 \\
\hline 9 & $(1,34-1=) 0,34$ & $(2,42-2=) 0,42$ & $(3,36-3=) 0,36$ & $(1,21-1=) 0,21$ & $(0,67-1=) 0,33$ & 1,00 \\
\hline 10 & $(1,49-1=) 0,49$ & $(2,69-3=)-0,31$ & $(3,73-3=) 0,73$ & $(1,34-1=) 0,34$ & $(0,75-1=)-0,25$ & 1,00 \\
\hline 11 & $(1,64-1=) 0,64$ & $(2,96-3=)-0,04$ & $(4,10-4=) 0,10$ & $(1,48-1=) 0,48$ & $(0,82-1=)-0,18$ & 1,00 \\
\hline 12 & $(1,79-2=)-0,21$ & $(3,22-3=) 0,22$ & $(4,48-4=) 0,48$ & $(1,61-1=) 0,61$ & $(0,90-1=)-0,10$ & 1,00 \\
\hline 13 & $(1,94-2=)-0,06$ & $(3,49-3=) 0,49$ & $(4,85-4=) 0,85$ & $(1,75-2=)-0,25$ & $(0,97-1=)-0,03$ & 1,00 \\
\hline 14 & $(2,09-2=) 0,09$ & $(3,76-3=) 0,76$ & $(5,22-5=) 0,22$ & $(1,88-2=)-0,12$ & $(1,04-1=) 0,04$ & 1,00 \\
\hline 15 & $(2,24-2=) 0,24$ & $(4,03-4=) 0,03$ & $(5,60-5=) 0,60$ & $(2,01-2=) 0,01$ & $(1,12-1=) 0,12$ & 1,00 \\
\hline Totaal geleverd & 2 & 4 & 6 & 2 & 1 & 15 \\
\hline
\end{tabular}

Een rangordelijst volgens het UWV. De volgorde van werknemers die voor ontslag in aanmerking komen wordt nu bepaald door het totaal aantal werknemers binnen de categorie uitwisselbare functie(s) te delen door het aantal werknemers binnen de leeftijdsgroep. Bij deze methode wordt geen rekening gehouden met het aantal gewenste ontslagen.

binnen die leeftijdsgroep het kortste dienstverband hebben. Dit kan leiden tot een volgend probleem met de rangordelijst zoals hierna beschreven.

\subsection{Onmogelijkheid de rangordelijst correct op te stellen}

We nemen in dit voorbeeld aan dat in januari 2016 een grote sollicitatieronde heeft plaatsgevonden voor een nieuwe functie, waardoor op 1 februari 2016 tien werknemers in dienst zijn getreden. Vier daarvan zitten in leeftijdsgroep 2 en vier daarvan in leeftijdsgroep 3 . Daarna zijn er geen werknemers meer bij gekomen. Het gevolg voor de afspiegeling is dat een keuze moet worden gemaakt tussen deze nieuwgedienden. Drie van de vier moeten in beide leeftijdsgroepen voor ontslag in aanmerking worden gebracht. Welke werknemers dit zijn, staat ter vrije bepaling van de werkgever. Lastiger wordt het als binnen twee leeftijdsgroepen hetzelfde getal wordt bereikt én werknemers op dezelfde datum in dienst zijn gekomen. Een simpel voorbeeld, waarbij het bedrijf tien werknemers op de te vervallen functies heeft zitten en vijf werknemers moeten afvloeien is te zien in tabel 6 .
Hetzelfde voorbeeld ziet er als op de methode van rangorde wordt gewerkt als volgt uit als te zien in tabel 7 .

Duidelijk te zien is dat bij stap 2 al niet meer kan worden bepaald uit welke leeftijdsgroep een werknemer moet worden ontslagen. In dat geval komt de keuze bij de werkgever te liggen, dus zover geen probleem. Voor het bepalen van de volgende stap ( stap 3 ) is het echter wel problematisch, aangezien niet duidelijk is en kan worden welke fractie het grootst is. Het ligt nu aan de (willekeurige) keus van de werkgever bij stap 2 hoe het in stap 3 verder gaat. Het Excelbestand van het UWV gaat niet in op deze problematiek. In de uitkomst van het bestand wordt zonder enige uitleg bepaald dat werkgever bij een gewenst aantal van vijf ontslagen drie werknemers uit leeftijdsgroep 2, één uit leeftijdsgroep 1 en één uit leeftijdsgroep 3 voor ontslag in aanmerking moet brengen. De werkgever wordt dus geen keuzemogelijkheid geboden, terwijl hij deze wel zou moeten krijgen. Let wel: nergens uit de Uitvoeringsregels blijkt dat anciënniteit in dit soort gevallen bepalend is voor de rangordelijst. Aangezien de werkgever die belast is met het bepalen van de ontslagvolgorde (tot voor kort) aan- 
Tabel 4

\begin{tabular}{|c|c|c|c|c|c|c|}
\hline Leeftijdsgroep & 1 (15-25 jaar) & 2 (25-35 jaar) & 3 (35-45 jaar) & 4 (45-55 jaar) & $5(55$ jaar +$)$ & TOTAAL \\
\hline Aantal groep $2 \mathrm{t} / \mathrm{m} 4$ & 3 & 0 & 1 & 3 & 2 & 9 \\
\hline \multicolumn{7}{|l|}{ Stap } \\
\hline 1 & 0,15 & 0,27 & 0,37 & 0,13 & 0,07 & 1,00 \\
\hline 2 & 0,30 & 0,54 & $-0,25$ & 0,27 & 0,15 & 1,00 \\
\hline 3 & 0,45 & $-0,19$ & 0,12 & 0,40 & 0,22 & 1,00 \\
\hline 4 & $-0,40$ & 0,07 & 0,49 & 0,54 & 0,30 & 1,00 \\
\hline 5 & $-0,25$ & 0,34 & 0,87 & $-0,33$ & 0,37 & 1,00 \\
\hline 6 & $-0,10$ & 0,61 & 0,24 & $-0,19$ & 0,45 & 1,00 \\
\hline 7 & 0,04 & $-0,12$ & 0,61 & $-0,06$ & 0,52 & 1,00 \\
\hline 8 & 0,19 & 0,15 & $-0,01$ & 0,07 & 0,60 & 1,00 \\
\hline 9 & 0,34 & 0,42 & 0,36 & 0,21 & $-0,33$ & 1,00 \\
\hline 10 & 0,49 & $-0,31$ & 0,73 & 0,34 & $-0,25$ & 1,00 \\
\hline 11 & 0,64 & $-0,04$ & 0,10 & 0,48 & $-0,18$ & 1,00 \\
\hline 12 & $-0,21$ & 0,22 & 0,48 & 0,61 & $-0,10$ & 1,00 \\
\hline 13 & $-0,06$ & 0,49 & 0,85 & $-0,25$ & $-0,03$ & 1,00 \\
\hline 14 & 0,09 & 0,76 & 0,22 & $-0,12$ & 0,04 & 1,00 \\
\hline 15 & 0,24 & 0,03 & 0,60 & 0,01 & 0,12 & 1,00 \\
\hline 16 & 0,39 & 0,30 & $-0,03$ & 0,15 & 0,19 & 1,00 \\
\hline 17 & $-0,46$ & 0,57 & 0,34 & 0,28 & 0,27 & 1,00 \\
\hline 18 & $-0,31$ & $-0,16$ & 0,72 & 0,42 & 0,34 & 1,00 \\
\hline 19 & $-0,16$ & 0,10 & 0,09 & 0,55 & 0,42 & 1,00 \\
\hline 20 & $-0,01$ & 0,37 & 0,46 & $-0,31$ & 0,49 & 1,00 \\
\hline $\begin{array}{l}\text { Totaal geleverd groep } 2 \\
\text { t/m } 4\end{array}$ & 3 & 3 & 4 & 3 & 2 & 15 \\
\hline
\end{tabular}

Om alle werknemers uit groep $2 \mathrm{t} / \mathrm{m} 4$ te vinden (die zeker voor ontslag in aanmerking moeten komen), moeten meer stappen worden gezet dan het gewenst aantal ontslagen.

gewezen is op het Excelbestand, is het voor die werkgever in meer complexe situaties niet te overzien wie nu wel en wie niet voor ontslag in aanmerking komt.

\subsection{De leemte in de rangordelijst}

In het rekenbestand van het UWV wordt eenmalig een rangorde gemaakt. In de methode die daarbij wordt gebruikt, wordt geen rekening gehouden met hoeveel ontslagen nodig zijn. Dit is vreemd. Bij de tabelmethode van paragraaf 3.1, waarbij een verdeling over de leeftijdsgroepen wordt gemaakt, gebeurt dat wel en voor de uitkomst van de afspiegeling maakt het dus verschil hoeveel werknemers voor ontslag moeten worden voorgedragen. Zo kan een bepaalde werknemer wel voor ontslag in aanmerking komen als maar vier ontslagen gewenst zijn, maar niet als de werkgever aangeeft dat hij een hoger aantal werknemers wil ontslaan. Zoals de berekening in figuur 1 , die uit het bestand van het UWV komt, laat zien, zijn het in het eerste geval werknemers A, B, C en D die voor ontslag moeten worden voorgedragen (de hoogsten in de rangorde) en in figuur 2 werknemers A, B, C, E en F (met grijs aangegeven en volgend uit de tabelmethode, dus over leeftijdsgroepen verdeeld).

Dat werknemer D niet consequent voor ontslag in aanmerking komt is in zoverre logisch, dat de verdeling over de leeftijdsgroepen anders wordt bij een ander aantal ontslagen. Bij vier ontslagen wordt het aantal werknemers in de leeftijdsgroep namelijk gedeeld door het totaal aantal werknemers, welk getal vervolgens verme- 


\begin{tabular}{|c|c|c|c|c|c|c|}
\hline Leeftijdsgroep & 1 (15-25 jaar) & 2 (25-35 jaar) & 3 (35-45 jaar) & 4 (45-55 jaar) & $5(55$ jaar + ) & TOTAAL \\
\hline Aantal groep $2 \mathrm{t} / \mathrm{m} 4$ & 3 & 0 & 1 & 3 & 2 & 9 \\
\hline \multicolumn{7}{|l|}{ Stap } \\
\hline 1 & 0,15 & 0,27 & 0,37 & 0,13 & 0,07 & 1,00 \\
\hline 2 & 0,30 & 0,54 & $-0,25$ & 0,27 & 0,15 & 1,00 \\
\hline 3 & 0,45 & $-0,19$ & 0,12 & 0,40 & 0,22 & 1,00 \\
\hline 4 & $-0,40$ & 0,07 & 0,49 & 0,54 & 0,30 & 1,00 \\
\hline 5 & $-0,25$ & 0,34 & 0,87 & $-0,33$ & 0,37 & 1,00 \\
\hline 6 & $-0,10$ & 0,61 & 0,24 & $-0,19$ & 0,45 & 1,00 \\
\hline 7 & 0,04 & $-0,12$ & 0,61 & $-0,06$ & 0,52 & 1,00 \\
\hline 8 & 0,19 & 0,15 & $-0,01$ & 0,07 & 0,60 & 1,00 \\
\hline 9 & 0,34 & 0,42 & 0,36 & 0,21 & $-0,33$ & 1,00 \\
\hline 10 & 0,49 & $-0,31$ & 0,73 & 0,34 & $-0,25$ & 1,00 \\
\hline 11 & 0,64 & $-0,04$ & 0,10 & 0,48 & $-0,18$ & 1,00 \\
\hline 12 & $-0,21$ & 0,22 & 0,48 & 0,61 & $-0,10$ & 1,00 \\
\hline 13 & $-0,06$ & 0,49 & $(0,85)$ & $-0,25$ & $-0,03$ & 1,00 \\
\hline 14 & 0,09 & $(0,76)$ & 0,22 & $-0,12$ & 0,04 & 1,00 \\
\hline 15 & 0,24 & 0,03 & $(0,60)$ & 0,01 & 0,12 & 1,00 \\
\hline 16 & 0,39 & 0,30 & $-0,03$ & 0,15 & 0,19 & 1,00 \\
\hline 17 & $-0,46$ & $(0,57)$ & 0,34 & 0,28 & 0,27 & 1,00 \\
\hline 18 & $-0,31$ & $-0,16$ & $(0,72)$ & 0,42 & 0,34 & 1,00 \\
\hline 19 & $-0,16$ & 0,10 & 0,09 & 0,55 & 0,42 & 1,00 \\
\hline 20 & $-0,01$ & 0,37 & 0,46 & $-0,31$ & 0,49 & 1,00 \\
\hline Totaal geleverd & 3 & 3 & 4 & 3 & 2 & 15 \\
\hline
\end{tabular}

Door een werknemer in te wisselen die zeker voor ontslag in aanmerking moet komen (groep $2 \mathrm{t} / \mathrm{m}$ 4) voor een werknemer uit groep 5, kan de rangorde worden bepaald. De werknemer uit leeftijdsgroep 3 die in stap 18 volgens de rangorde voor ontslag in aanmerking komt, komt dit niet meer door de werknemer uit leeftijdsgroep 5 die zeker voor ontslag in aanmerking moet worden gebracht. Op dezelfde wijze zijn werknemers uit stap 13, 15 en 17 niet meer nodig om aan het gewenste aantal ontslagen te komen.

nigvuldigd wordt met vier. Moet van vijf werknemers afscheid worden genomen, dan wordt het getal vermenigvuldigd met vijf. Zo ontstaat een andere verdeling (lees: andere fracties) en kan het voorkomen dat een leeftijdsgroep iemand minder hoeft te leveren, omdat een andere leeftijdsgroep een hoger geheel getal krijgt. Het probleem van dit voorbeeld en daarmee van de twee verschillende methoden van het UWV is dat in de situaties waarbij de tabelmethode geen soelaas biedt, altijd de rangorde wordt gebruikt. De rangorde wordt maar één keer vastgesteld en wel over alle werknemers en precies daar gaat het fout. Uit het voorbeeld blijkt nu juist dat de rangorde afhankelijk is van het aantal benodigde ontslagen. Het UWV past dus de rangorde naar mijn mening verkeerd toe. Dat het probleem zit in de wis- kundige berekenmethode die ten grondslag ligt aan de rangordelijst, leg ik in de volgende paragraaf uit.

\section{De wiskundige benadering van de UWV-methode}

$\mathrm{Nu}$ is vastgesteld dat het $\mathrm{UWV}$ een andere (tweede) methode hanteert wanneer de tabelmethode geen uitsluitsel biedt, is het interessant te bezien of de manier van rekenen die ten grondslag ligt aan de rangordelijst, wel correct is vanuit het oogpunt van de afspiegeling. Zonder al te veel een wiskundige insteek te kiezen, kan worden beredeneerd dat een betere methode voorhan- 


\begin{tabular}{|c|c|c|c|c|c|c|}
\hline Leeftijdsgroep & 1 (15-25 jaar) & 2 (25-35 jaar) & 3 (35-45 jaar) & 4 (45-55 jaar) & $5(55$ jaar +$)$ & TOTAAL \\
\hline Aantal werknemers & 1 & 6 & 1 & 1 & 1 & 10 \\
\hline Verdeling & 0,500 & 3,000 & 0,500 & 0,500 & 0,500 & 5 \\
\hline $\mathrm{Na}$ gehele getallen & 0 & 3 & 0 & 0 & 0 & 3 \\
\hline O.b.v. decimalen & $?$ & & $?$ & $?$ & $?$ & 0 \\
\hline Totaal & $?$ & 3 & $?$ & $?$ & $?$ & 3 \\
\hline
\end{tabular}

De methode waarbij een verdeling over leeftijdsgroepen wordt gemaakt, biedt soms geen uitkomst. Immers, leeftijdsgroep 1, 3, 4 en 5 hebben dezelfde fractie 0,5 en de werknemers in deze leeftijdsgroepen zijn op dezelfde datum in dienst getreden.

Tabel 7

\begin{tabular}{|c|c|c|c|c|c|c|}
\hline Leeftijdsgroep & 1 (15-25 jaar) & 2 (25-35 jaar) & 3 (35-45 jaar) & 4 (45-55 jaar) & $5(55$ jaar +$)$ & TOTAAL \\
\hline \multicolumn{7}{|l|}{ Stap } \\
\hline 1 & 0,10 & 0,60 & 0,10 & 0,10 & 0,10 & 1,00 \\
\hline 2 & $0,20 ?$ & $0,20 ?$ & $0,20 ?$ & $0,20 ?$ & $0,20 ?$ & 1,00 \\
\hline 3 & 0,30 & 0,80 & 0,30 & 0,30 & 0,30 & 2,00 \\
\hline 4 & 0,40 & 0,40 & 0,40 & 0,40 & 0,40 & 2,00 \\
\hline 5 & 0,50 & 1,00 & 0,50 & 0,50 & 0,50 & 3,00 \\
\hline
\end{tabular}

Ook in de methode van rangorde leiden sommige personeelsbestanden tot problemen.

den is. Het doel van afspiegelen is de verdeling over leeftijdsgroepen voor en na de ontslagronde zo veel mogelijk hetzelfde te houden. Als de ontslagen procentueel over de leeftijdsgroepen worden verdeeld moeten de percentages voor en na de ontslagen per leeftijdsgroep nagenoeg hetzelfde zijn. De enige reden voor een grote afwijking tussen het percentage voor en na de ontslagen is dat de bijzondere werknemers uit groep 2 tot en met 4 daarvoor zorgen. Als binnen een leeftijdsgroep meer bijzondere werknemers zitten dan op grond van de afspiegeling voor ontslag zouden moeten worden voorgedragen, zal het percentage na de ontslagronde altijd lager liggen dan voor de ontslagronde. Er resteren immers minder werknemers in die leeftijdsgroep dan op grond van de afspiegeling zou moeten. Het gevolg voor de andere leeftijdsgroepen is dat het percentage juist hoger wordt.

In situaties waarbij het aantal bijzondere werknemers in een leeftijdsgroep niet hoger is dan het aantal werknemers dat volgens een normale verdeling (tabelmethode) over de leeftijdsgroepen ontslagen moet worden, zijn de percentages ook niet altijd gelijk. Zoals in voorgaande voorbeelden te zien is, worden 'restanten' aan een leeftijdsgroep toebedeeld teneinde het gewenste aantal ontslagen te realiseren. Op basis van de hoogste fractie moet een leeftijdsgroep een extra werknemer leveren. Hierdoor daalt het percentage na ontslag binnen die leeftijdsgroep. Het gevolg is dat binnen een andere leef- tijdsgroep het percentage stijgt. $\mathrm{Nu}$ zijn twee opties mogelijk. De eerste is dat één percentage zo dicht mogelijk bij het origineel komt te liggen en het andere daarmee ver afwijkt. Zie tabel 8 .

De tweede optie is dat beide percentages van die leeftijdsgroepen zo dicht mogelijk bij het origineel liggen, maar daardoor allebei ver afwijken, zoals te zien in tabel 9 .

Gezien het doel van afspiegelen ligt deze optie meer voor de hand. ${ }^{8}$ Een simpeler voorbeeld wijst dat uit: als de helft van het totaal aantal werknemers ontslagen moet worden, dan moet de verdeling per leeftijdscategorie voor het ontslag $100 \%$ zijn en de verdeling na ontslag $50 \%$ van het aantal werknemers per leeftijdsgroep: elke leeftijdsgroep draagt procentueel hetzelfde bij. Door de rangorde van alle werknemers vast te stellen en die volgorde niet afhankelijk van het aantal gewenste ontslagen te maken, worden niet altijd de juiste werknemers voor ontslag voorgedragen. De verhoudingen tus-

8. Ook wiskundig gezien is dit de beste optie, al hangt het volgens wiskundigen af van de grootte van de getallen waarmee wordt gerekend. Hoe kleiner de getallen, des te meer verdeeld de meningen. Is het gewenst aantal ontslagen hoger, bijvoorbeeld tien werknemers, dan geldt deze theorie. Zie voor meer informatie: Kenneth Benoit, 'Wich Electoral Formula Is the Most Proportional? A New Look with New Evidence', Political Analysis, 8:4. 
Figuur 1

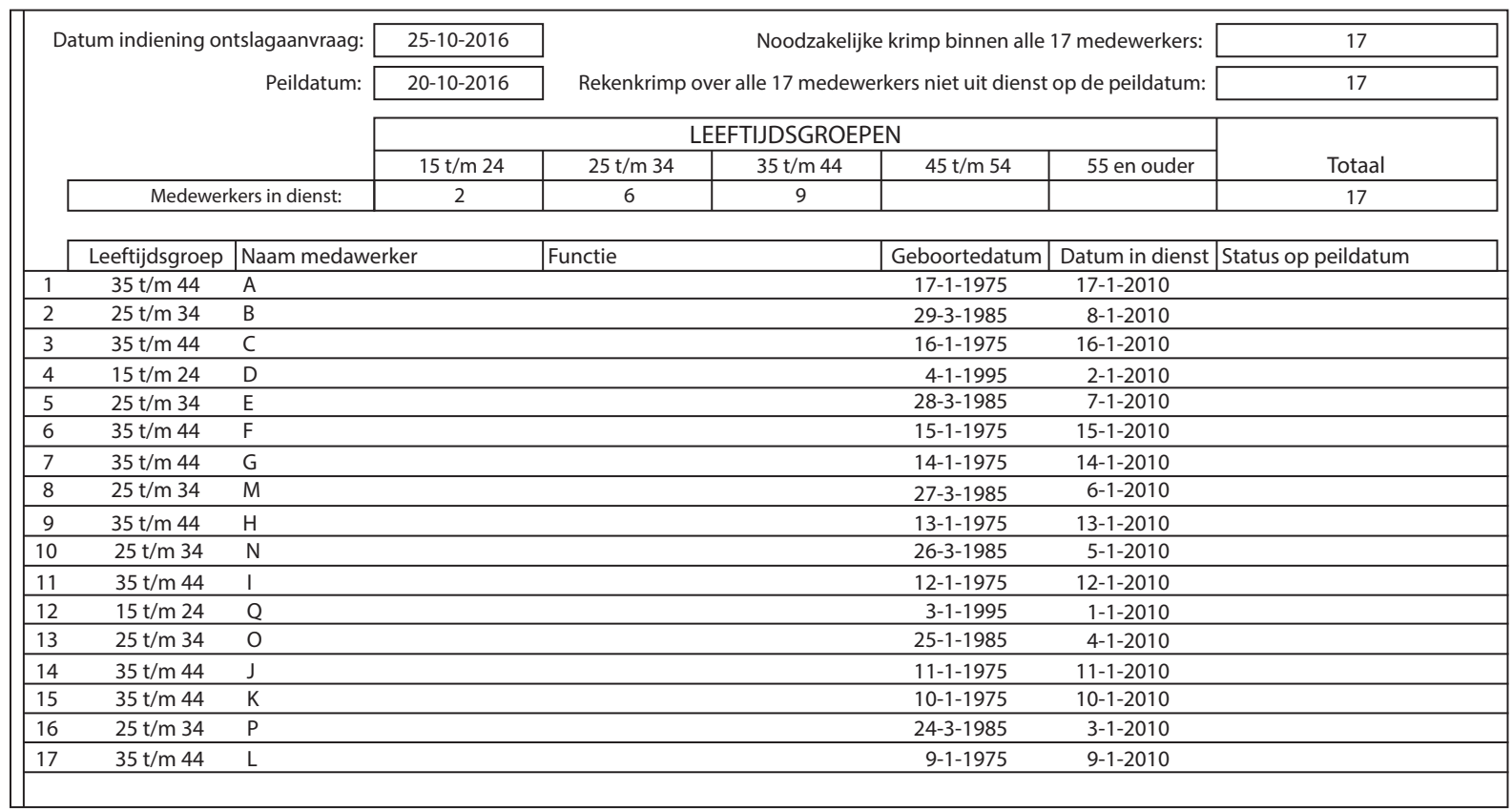

Rangorde bij het personeelsbestand. Werknemers A, B, C en D zouden voor ontslag in aanmerking komen. Wordt gekozen voor vier ontslagen, dan volgen daar dezelfde vier werknemers uit. In de figuur is te zien dat het UWV uitgaat van alle aanwezige werknemers, zonder dat de gebruiker daarin iets te kiezen heeft.

Figuur 2

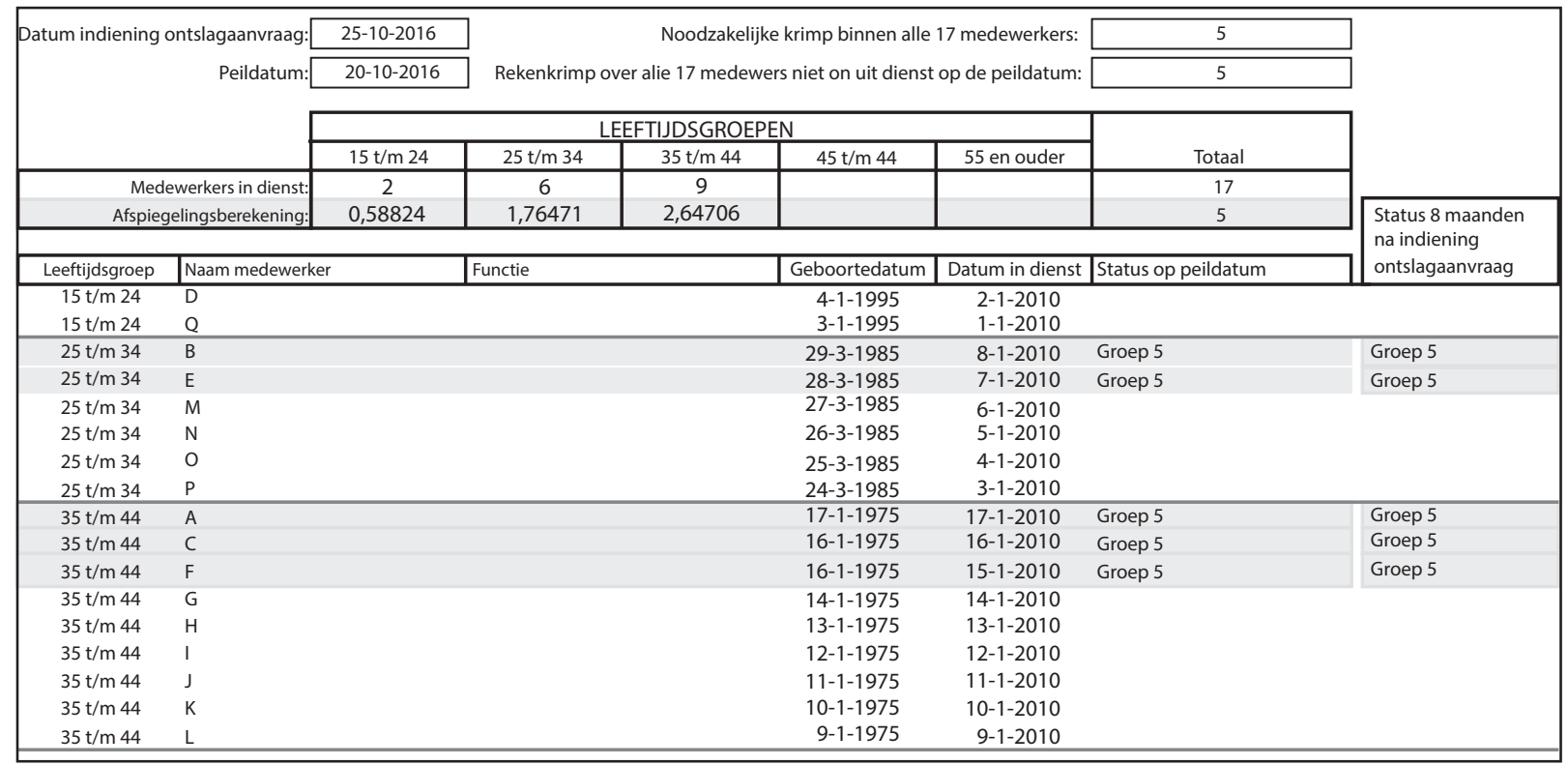

Werknemers die voor ontslag in aanmerking komen als voor vijf ontslagen worden gekozen: $A, B, C, E$ en $F$, met grijs aangegeven. D hoeft niet meer voorgedragen te worden.

sen de situatie vóór en na het ontslag lopen daardoor ook uiteen. Bij het UWV gebeurt dat inderdaad. Bij het UWV is de ene leeftijdsgroep bijvoorbeeld met $30 \%$ ingekrompen, terwijl bij de andere leeftijdsgroepen het gemiddelde rond de 20\% ligt. Precies dit laatste is niet gewenst, nu de verdeling bij alle leeftijdsgroepen rond hetzelfde percentage zou moeten liggen. Natuurlijk kan sprake zijn van vreemde procentuele afwijkingen als gevolg van grote aantallen in de groepen 2 tot en met 4, maar dat staat los van dit voorbeeld. In tabel 8 en 9 staan alleen werknemers uit groep 5. De rare 'piek' binnen een leeftijdsgroep moet wanneer dat kan worden voorkomen en een evenredige verdeling moet de voorkeur krijgen. 
Tabel 8

\begin{tabular}{lrrrrrr}
\hline Leeftijdsgroep & $\mathbf{1}(\mathbf{1 5 - 2 5}$ jaar) & $\mathbf{2 ( 2 5 - 3 5}$ jaar) & $\mathbf{3}(\mathbf{3 5 - 4 5}$ jaar) & $\mathbf{4}(\mathbf{4 5 - 5 5}$ jaar) & $\mathbf{5}(\mathbf{5 5}$ jaar +) & TOTAAL \\
\hline Vóór afspiegeling & $14,93 \%$ & $26,87 \%$ & $37,31 \%$ & $13,43 \%$ & $7,46 \%$ & $\mathbf{1 0 0 , 0 0 \%}$ \\
\hline Na afspiegeling & $16,36 \%$ & $21,82 \%$ & $41,82 \%$ & $14,55 \%$ & $5,45 \%$ & $100,00 \%$ \\
\hline Verschil & $1,44 \%$ & $-5,05 \%$ & $4,50 \%$ & $1,11 \%$ & $-2,01 \%$ & $0,00 \%$
\end{tabular}

De methode van het UWV kent een kleine afwijking en een uitschieter. Het percentage van $-5,05$ is een nog grotere afwijking, maar zoals in tabel 9 kan worden gezien, is deze onvermijdelijk.

Tabel 9

\begin{tabular}{lrrrrrr}
\hline Leeftijdsgroep & $\mathbf{1}(\mathbf{1 5 - 2 5}$ jaar) & $\mathbf{2 ( 2 5 - 3 5 \text { jaar } )}$ & $\mathbf{3}(\mathbf{3 5 - 4 5}$ jaar) & $\mathbf{4}(\mathbf{4 5 - 5 5}$ jaar $)$ & $\mathbf{5}(\mathbf{5 5}$ jaar +) & TOTAAL \\
\hline Vóór afspiegeling & $14,93 \%$ & $26,87 \%$ & $37,31 \%$ & $13,43 \%$ & $7,46 \%$ & $\mathbf{1 0 0 , 0 0 \%}$ \\
\hline Na afspiegeling & $16,36 \%$ & $21,82 \%$ & $40,00 \%$ & $16,36 \%$ & $5,45 \%$ & $100,00 \%$ \\
\hline Verschil & $1,44 \%$ & $-5,05 \%$ & $2,69 \%$ & $2,93 \%$ & $-2,01 \%$ & $0,00 \%$
\end{tabular}

Deze verdeling past beter bij het doel van afspiegelen: zo veel mogelijk de situatie voor en na de ontslagen hetzelfde houden.

\section{Conclusie}

Afspiegelen is en blijft een lastige opgave. Het UWV heeft de regels daarover terecht aangepast. Het is wenselijk dat, ten eerste, ook nog de Uitvoeringsregels worden verduidelijkt. De rekenvoorbeelden en uitleg die het UWV geeft, bieden voor veel situaties geen oplossing. Voor de werkgever en de werknemer is het daarom niet duidelijk welke werknemers voor ontslag in aanmerking moeten worden gebracht. Zij kunnen daartoe wel het Excelbestand van het UWV gebruiken, maar dat bestand geeft voor sommige situaties een verkeerde uitkomst, althans een uitkomst die niet in alle gevallen in overeenstemming is met de uitkomst die een redelijke toepassing van de geldende regels met zich brengt. Onterecht worden immers bepaalde werknemers voor ontslag in aanmerking gebracht. De methode waarbij werknemers op uitwisselbare functies worden verdeeld over leeftijdsgroepen, waarna met gehele getallen en fracties wordt bepaald wie voor ontslag in aanmerking komen, wordt niet consequent gebruikt. Dat kan ook niet en daarom is de methode niet geschikt voor de bepalen van de afspiegeling. Het werken met een rangordelijst, dat het UWV als alternatief gebruikt, wordt niet in de Uitvoeringsregels beschreven. Ook dat leidt voor werkgever en werknemer tot moeilijkheden. Daarnaast is de methode in zoverre niet goed, dat soms verkeerde werknemers voor ontslag in aanmerking komen. Omdat het UWV bij het bepalen van de rangordelijst geen rekening houdt met het aantal ontslagen dat moet worden gerealiseerd, ontstaat een onjuiste rangorde. Met de methode wordt het doel van afspiegelen niet bereikt: de verhoudingen tussen de leeftijdsgroepen is na de ontslagronde niet zo veel mogelijk gelijk aan de verdeling over leeftijdsgroepen zoals deze voor het ont- slag bestond. Een betere methode is voorhanden en zou dan ook moeten worden gebruikt. Met die methode wordt constant gekeken naar de proportionaliteit, die afhankelijk is van het gewenste aantal ontslagen. 